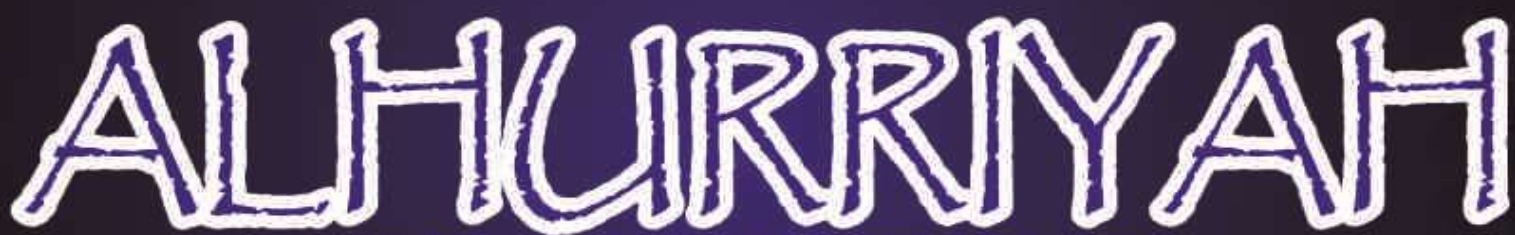

JURNAL HUKUM ISLAM

Kedudukan Bak Pencuci Kaki

Sebelum Masuk dan Keluar Tempat Berwudhuk

Dalam Tinjauan Fiqh Ibadah

Busyro \& Saiful Amin

Relevansi Hukum Islam Dalam Perumusan

Rancangan KUHP Baru

Aris Irawan \& Asneliwarni

Analisis Putusan Dalam Pengalihan Talak Raj'i Menjadi Talak Bain Perkara No.0067/PDT.G/2016/PALK (Studi Kasus Di Pengadilan Agama Kab. Limapuluh Kota)

Nurul Fadhilah \& Fajrul Wadi

Nikah Misyar (Analisis Magashid Asy-Syari'ah) Syahrial Dedi

Hukum Merokok Dalam Islam

(Studi Nash-nash Antara Haram dan Makruh)

Muhamad Rezi \& Sasmiarti

Filsafat Politik Islam Tentang Kedudukan

Mantan Narapidana Menjadi Anggota Legislatif

Andriko \& Adlan Sanur

Kebebasan Berpendapat dan Informasi:

Tinjauan Filosofis Terhadap Pasal 22 Deklarasi Kairo Abd Rahman

Studi Komparatif Terhadap Ulama Hanafiyyah dan Syafi'iyyah Tentang Wakaf Tunai

Rahmat Hidayat \& Dahyul Daipon 


\title{
KEDUDUKAN BAK PENCUCI KAKI SEBELUM MASUK DAN KELUAR TEMPAT BERWUDHUK DALAM TINJAUAN FIQH IBADAH
}

\author{
Busyro \\ Fakultas Syari'ah IAIN Bukittinggi, busyro.pro18@gmail.com \\ Saiful Amin \\ Fakultas Syariah IAIN Bukittinggi, saifulamin680@gmail.com
}

\begin{abstract}
\begin{tabular}{l|l|l} 
Diterima: 5 Februari 2018 & Direvisi : 25 April 2018 & Diterbitkan: 30 Juni 2018
\end{tabular}
\end{abstract}

\begin{abstract}
The purity of limbs from any dirtiness is one of requirement which must be fulfilled before shalat. That is why many Ulama were explaining this case deeply. In this paper, the study of it was the character of the water which was pure and purified that can be used for wudhu, and which was not. In Bukittinggi, most of management mosques provide small basin with full water in front of wudhu room. It was aimed to facilitate people cleaning their feet before come into mosque. Yet, some of the basins have provided with no flowing water and less than two qullah (jars). Moreover, some of mosques only have one basin in one way (in and out of wudhu room). Basically, every feet of Muslim that get into the basin will do not affect anything to the pool. However, the problem was generated by the purity of the feet that some of them may unclean and take the water into effect. That is to say that providing the basin in front of wudhu room is obnoxious (makrûh) based on precaution (ibutyâth) principle.
\end{abstract}

Keywords: Bak pencuci kaki, wudhuk, bernajis, dua qullah

\begin{abstract}
Abstrak
Kesucian anggota tubuh dari najis merupakan salab satu syarat untuk sahnya ibadah shalat yang dilakukan oleh seorang muslim. Oleh karena itu berbagai aturan dalam membersibkan diri sebelum shalat dibahas secara mendalam oleh ulama figh. Salah satu pembahasan yang terkait dengan hal itu adalah persoalan air yang boleh dipakai untuk berwudhuk, yang intinya merupakan air suci dan dapat mensucikan. Untuk menjaga kesucian jamaah yang akan memasuki masjid, maka sebagian pengurus masjid membuat bak kecil untuk mencuci kaki sebelum masuk dan keluar dari tempat berwudhuk. Namun pada sebagian masjid, air yang terdapat pada bak tersebut tergenang, tidak mengalir, dan kurang dua qullah. Di samping itu hanya tersedia satu buah bak, tempat masuk berwudhuk dan sekaligus tempat keluar dan selanjutnya masuk ke dalam masjid. Pada dasarnya kaki seorang muslim yang menginjak air yang tergenang tidak akan membuat air itu bernajis, tetapi mengingat beragamnya kondisi kaki yang masuk dimungkinkan ada najis yang tertinggal di air genangan itu. Oleh karena itu berdasarkan prinsip ibtiyath, membuat bak seperti itu bukumnya makruh.
\end{abstract}

Kata Kunci: Bak pencuci kaki, wudhuk, bernajis, dua qullah

\section{PENDAHULUAN}

Wudhuk merupakan perbuatan wajib yang dilakukan oleh seorang muslim sebelum melaksanakan shalat. Sah atau tidak sahnya shalat seseorang salah satunya tergantung kepada sah dan tidak sahnya wudhuk yang dilakukannya. Hal ini sesuai dengan sabda Nabi SAW yang diriwayatkan oleh Bukhârî dan Muslim dari Abû Hurairah yang berbunyi:

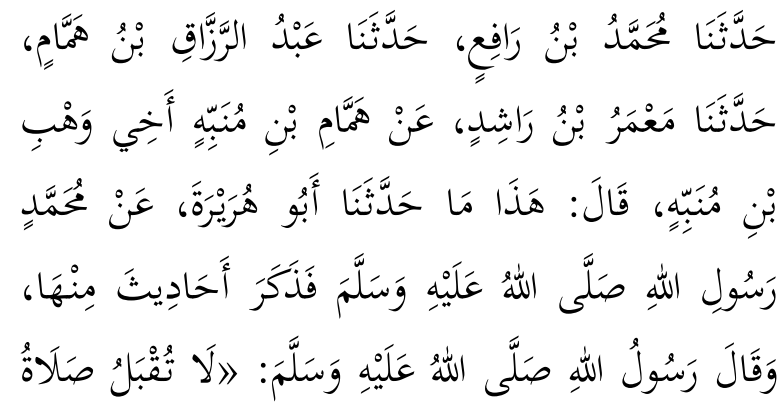




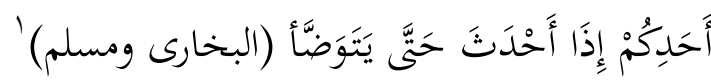

Telah memberitakan kepada kami Muhammad ibn Râfi', telab memberitakan kepada kami 'Abd alRazzâa ibn Hammâm, telab memberitakan kepada kami Ma'mar ibn Rasyî̀ dari Hammâm ibn Munabbih saudara dari Wabhâb ibn Munabbih, ia berkata, Abû Hurairah ra berkata, telah bersabda Rasulullab SAW: "Tidak diterima shalat salah seorang dari kalian ketika ia berhadas sampai ia melakukan wudhuk". (HR Bukhârî dan Muslim).

Wudhuk yang menyebabkan shahnya shalat tentunya sangat terkait dengan syarat dan tata cara wudhuk yang benar dan sesuai dengan tuntunan syarak. Di antara bagian penting yang patut diketahui di seputar wudhuk adalah air yang boleh dipakai oleh seseorang untuk berwudhuk. Dalam hal ini ulama sudah membahas panjang lebar terkait dengan persoalan ini di dalam berbagai kitab fiqh mereka. Walaupun ada perbedaan pendapat ulama dalam menentukan air yang layak untuk berwudhuk, tetapi mereka menyepakati bahwa kategori air itu adalah air yang suci dan dapat mensucikan. Satu hal lagi menjadi kesepakatan mereka adalah bahwa shalat tidak sah apabila salah satu anggota tubuh terkena najis. Hal ini menunjukkan bahwa memelihara anggota tubuh, khusus anggota wudhuk, dari terkena najis merupakan sesuatu yang harus diupayakan oleh seorang muslim.

Eksistensi wudhuk pada dasarnya adalah untuk menghilangkan hadas kecil, sehingga tidak semua anggota tubuh dibasuh dengan air. Hal ini tentunya berbeda dengan aktifitas membersihkan diri dari kotoran dan najis. Membersihkan diri dari kotoran dan najis biasanya disebut dengan istinjầ. Oleh karena

${ }^{1}$ Muhammad ibn Ismâ'îl Abu Abdillâh alBukhârî al-Ja'fîy, al-Jâmi al-Musnad al-Shahîh alMukhtashar min Umûr Rasûlillâh $S A W$ wa Sunanub wa Ayyâmuh, (Dâr al-Thawwâf al-Najâh, [tth]), juz 1, 39; juga Muslim ibn Hajjâj Abû al-Hasan al-Qusyairî alNaisabûrî, al-Musnad al-Shahîh al-Mukhtashar Bi Naql al'Adl Ilâ Rasûlillâh $S A W$, (Beirut: Dâr Ihyâ' al-Turâts al'Arabiy, [tth]), juz 1, 203 itu aktifitas berwudhuk tidak berkaitan secara langsung dengan membersihkan anggota badan dari kotoran, tetapi lebih kepada mengikuti sunnah yang mahdhah untuk menghilangkan hadas. Dengan demikian mensucikan diri dari hadas dapat dikatakan sebagai kebersihan batin, sedangkan mensucikan diri dari kotoran dan najis (istinjâ) merupakan kebersihan jasmani. Kedua-dua bentuk kebersihan ini perlu diperhatikan oleh seorang muslim sebelum menghadap kepada Allah SWT (shalat).

Persoalan yang muncul dalam berwudhuk atau menghilangkan hadas di satu pihak dengan membersihkan diri dari kotoran dan najis pada sisi lain merupakan satu kesatuan yang tidak terpisahkan. Kebersihan batin dan kebersihan lahiriyah merupakan syarat yang diwajibkan sebelum menghadap kepada Allah SWT (shalat). Apabila keduanya tidak berjalan beriringan, maka tentunya akan berpengaruh kepada diterima dan tidak diterimanya shalat seseorang. Oleh karena itu seseorang perlu memperhatikan keduanya sekaligus.

Pada sebagian masjid yang ada di kota Bukittinggi dan juga pada beberapa masjid lainnya di beberapa tempat, ada inisiatif dari pengurus masjid untuk menciptakan kebersihan tempat berwudhuk mulai dari masuknya seseorang ke tempat bewudhuk sampai seseorang masuk ke dalam masjid. Di antara cara cara yang dilakukan adalah dengan membuatkan bak air kecil tempat mencuci kaki sebelum masuk dan keluar tempat berwudhuk. Pada dasarnya apa yang dilakukan itu merupakan sebuah inisiatif yang patut diapresiasi. Inisiatif tersebut, dari yang terlihat dan teramati dapat dikelompokkan kepada empat bentuk;

1. Membuat bak kecil membasuh kaki sebelum masuk tempat berwudhuk dan di bak itu juga nantinya kaki kembali dibasuh sebelum masuk ke dalam masjid dan airnya kurang dari dua qullah dan tidak mengalir; 
2. Membuat bak kecil membasuh kaki sebelum masuk tempat berwudhuk dan di bak itu juga nantinya kaki kembali dibasuh sebelum masuk ke dalam masjid dan airnya lebih dari dua qullah dan tidak mengalir;

3. Ketiga, membuat bak kecil pembasuh kaki sebelum masuk tempat berwudhuk, sedangkan untuk keluar dari tempat berwudhuk dibuat bak yang lain. Artinya ada dua bak pembasuh kaki yang berbeda antara tempat masuk dan keluar tempat berwudhuk, dan airnya kurang dari dua qullah dan tidak mengalir;

4. Keempat, membuat bak kecil pembasuh kaki sebelum masuk tempat berwudhuk, sedangkan untuk keluar dari tempat berwudhuk dibuat bak yang lain yang airnya dua qullah atau lebih serta mengalir.

Keempat bentuk inovasi bak kecil pembasuh kaki itu mungkin tidak perlu dibicarakan ketika air pada bak kecil itu mengalir atau air pada bak itu lebih dari qullah. Hal disimpulkan berdasarkan informasi hadis yang diriwayatkan antara lain oleh Abû Dâwûd, al-Nasâ'î dan ibn Mâjah, disebutkan bahwa air yang sampai dua qullah tidak dapat dinajisi oleh apapun. ${ }^{2}$ Tetapi dalam pengamatan sementara, ternyata tidak semua bak kecil itu mempunyai kriteria di atas. Hal ini tentu menimbulkan pertanyaan, tidak hanya bagi penulis sendiri, tetapi juga pernah ditanyakan oleh beberapa orang jamaah. Jawaban dari hal ini tentu saja tidak ditemukan dalam literatur-literatur fiqh klasik, sehingga hukumnya pun belum jelas. Berkenaan dengan hal inilah tulisan ini dibuat, agar ditemukan solusi yang lebih tepat dan tidak mengganggu kepada kebersihan batiniyah dan lahiriyah

2 Abû Dâwûd Sulaimân ibn al-Asy'ab ibn Ishâq ibn Basyîr ibn Syidâd ibn Umar a-Azadi, Sunan Abı̂ Dâwûd, (Beirut: al-Maktabah al-'Ishriyah, [tth]), juz 1, 17; Abû Abdirrahmân Ahmad ibn Syu'aib ibn Ali alKharasânîy al-Nasầîy, al-Sunan al-Shughrâ li al-Nasầyyy, (Halab: Maktab al-Mathbu'ât al-Islâmiyah, 1987), juz 1, 46; dan Ibn Mâjah Abû Abdillâh Muhammad ibn Yazîd al-Quzwainîy, Sunan Ibn Mâjah, (Dâr al-Ihyâ` al-Kutub al-'Arabiyah, [tth]), juz 1, 172 sebagaimana disampaikan sebelumnya.

Untuk menfokuskan penyampaian, dalam tulisan ini tidak akan membahas tentang rukun dan syarat wudhuk, tetapi lebih menfokuskan kepada persoalan air yang dipakai untuk mencuci salah satu anggota wudhuk sebelum dan setelah selesai berwudhuk. Artinya ketika seseorang selesai melaksanakan wudhuknya dengan air yang suci lagi mensucikan, maka diyakini wudhuknya sudah sah, tetapi memasukkan kaki ke dalam bak kecil setelah selesai berwudhuk dengan kondisi airnya yang tergenang dan tidak sampai dua qullah dan tidak mengalir merupakan persoalan utama dalam tulisan ini.

\section{SEPINTAS KAJIAN WUDHUK}

Wudhuk adalah sebuah aktifitas seorang muslim sebelum melaksanakan shalat. Secara bahasa kata wudbû atau widhâah merupakan masdar dari kata wadha'a atau wadhi $a$, yang berarti baik dan bersih. ${ }^{3}$ Dengan demikian aktifitas wudhuk merupakan salah satu cara yang dilakukan oleh seorang muslim untuk memperoleh kebaikan dan kebersihan diri mereka, dalam hal ini adalah membersihkan diri dari hadas.

Wudhuk disyariatkan kepada umat Islam bersamaan dengan disyariatkannya shalat pada peristiwa Isra dan Mi'raj Nabi Muhammad SAW. ${ }^{4}$ Dalil-dalil yang dijadikan landasan hukum diwajibkannya wudhuk terdapat dalam al-Qur`an, Sunnah, dan Ijmak Ulama. Dalam QS al-Maidah [5]: 6 Allah SWT berfirman:

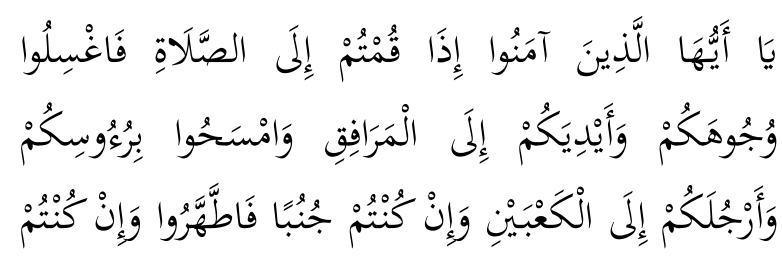

${ }^{3}$ Lihat Ahmad Warson Munawwir, Kamus AlMunawwir, (Yogyakarta: Pustaka Progresif, 1997), 1564; juga 'Abd al-Rahmân al-Jazîrî, al-Figh 'Alâ Madzâabib alArba'ah, (Kairo: Mathba'ah Istiqâmah, [tth]), juz 1, 46

4 Zain al-Dîn ibn 'Abd al-Azîz al-Malibârî, Fath al-Mu'în bi Syarh al-Qurrata al-'Uyûn, (Semarang: Karya Toha Putra, [tth]), 18 


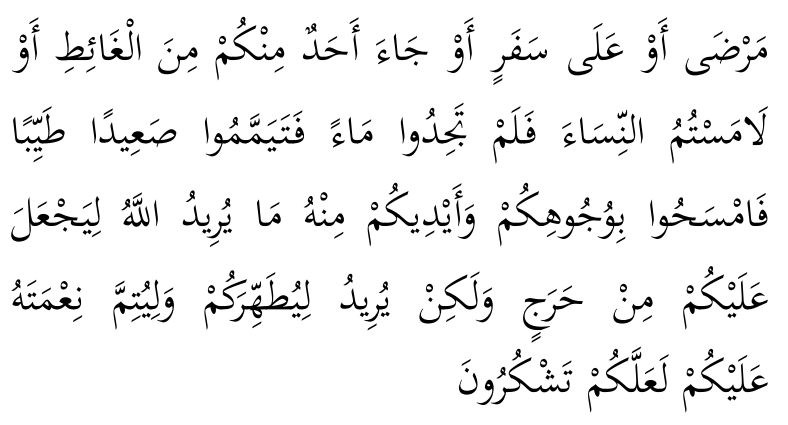

Hai orang-orang yang beriman, apabila kamu hendak mengerjakan shalat, Maka basublab mukamu dan tanganmu sampai dengan siku, dan sapulah kepalamu dan (basub) kakimu sampai dengan kedua mata kaki, dan jika kamu junub maka mandilah, dan jika kamu sakit atau dalam perjalanan atau kembali dari tempat buang air (kakus) atau menyentuh perempuan, lalu kamu tidak memperoleh air, maka bertayammumlah dengan tanah yang baik (bersib); sapulah mukamu dan tanganmu dengan tanah itu. Allah tidak hendak menyulitkan kamu, tetapi Dia bendak membersibkan kamu dan menyempurnakan nikmat-Nya bagimu, supaya kamu bersyukur.

Di dalam Sunnah-pun, ketentuan kewajiban wudhuk ini diriwayatkan oleh seluruh ulama hadis, di antara adalah hadis yang diriwayatkan oleh Bukhârî dan Muslim, ${ }^{5}$ sedangkan dalil lainnya berupa ijmak ulama bahwa hal ini sudah berlaku semenjak zaman Nabi SAW sampai sekarang dan merupakan suatu kewajiban agama yang amat penting. ${ }^{6}$

Dari ayat di atas dan juga penjelasanpenjelasan Nabi SAW serta pendapat ulama dapat disebutkan bahwa rukun-rukun wudhuk itu dimulai dengan berniat, karena ada hadis Nabi SAW yang menyebutkan bahwa setiap memulai amalan haruslah dengan niat; ${ }^{7}$ membasuh muka, membasuh kedua tangan

5 Muhammad ibn Ismâ'îl Abû Abdillâh alBukhârî al-Ja'fîy, al-Jâmi' al-Musnad..., 39 dan Muslim ibn Hajjâj Abû al-Hasan al-Qusyairî al-Naisabûrî, alMusnad al-Shahî.., 203

${ }^{6}$ Sayyid Sâbiq, Fiqh al-Sunnah, (Kairo: Thabâ'ah Khassah al-Fathu Li al-I'lâm al-'Arabi, 1365 H), juz 1, 28

${ }^{7}$ Muhammad Fu'âd 'Abd al-Bâqi, al-Lu'lu' wa alMarjân fì Mâ Ittifâq al-Syaikhân, (Beirut Libanon: Dâr alFikr, [tth]), juz 1, 2 sampai ke siku, mengusap kepala, dan membasuh kaki sampai mata kaki. Sedangkan mengusap kedua telinga merupakan praktek Rasulullah SAW yang dilakukan setelah mengusap kepala, yang bagi sebagian ulama dinyatakan sebagai amalan yang sunat hukumnya. Secara sederhana begitulah rangkaian ibadah wudhuk dilakukan.

Adapun hal-hal yang membatalkan wudhuk cukup banyak, salah satunya sebagaimana ditulis oleh Syekh al-Ghâzi dalam kitab Fath al-Qarîb. Menurutnya ada lima hal yang dapat membatalkan wudhuk seseorang, yaitu; pertama keluarnya sesuatu dari qubul dan dubur (angin atau cairan); kedua, tidur dalam posisi tidak tetapnya pantat di lantai; ketiga, hilang akal yang disebabkan oleh mabuk, sakit, gila, ayan dan sebagainya; keempat, terjadinya persintuhan antara laki-laki dan perempuan yang bukan mahram tanpa ada pembatas, walaupun yang disentuh sudah menjadi mayat; dan kelima, seseorang menyintuh kemaluannya atau kemaluan orang lain dengan punggung atau telapak tangannya, baik disentuh sendiri atau disentuh oleh orang lain, baik disentuh oleh orang dewasa maupun anak kecil, laki-laki ataupun perempuan, bahkan menyintuh kemaluan mayat sekalipun. ${ }^{8}$

Pembahasan tentang rukun wudhuk dan hal-hal yang membatalkan wudhuk sebenarnya sangat luas karena cukup banyak perbedaan pendapat ulama di dalamnya untuk setiap item yang dibicarakan. Namun dari sekian banyak pendapat hukum yang dikemukakan ulama dalam berbagai mazhabnya, tidak ditemukan adanya akibat hukum dari merendamkan kaki ke dalam air yang tergenang dan tidak mengalir sesudah melakukan wudhuk. Apalagi air tersebut dipakai oleh banyak orang (musta'mal) dan dimungkinkan dimasuki oleh najis (mutanajjis), baik terlihat ataupun tidak terlihat.

8 Muhammad ibn al-Qâsim al-Ghâzî, Fath alQarîb al-Mujî̀, (Indonesia: Dâr al-Ihyầ al-Kitâb al'Arabiyah, [tth]), 6 


\section{MACAM-MACAM AIR DAN HUBUNGANNYA DENGAN KESUCIAN}

Ulama fiqh sudah membagi kategori air dan hubungannya dengan kebolehan dipakai sebagai alat bersuci atau tidak. Pada dasarnya pembagian itu dapat dilihat kepada empat atau lima kategori, yaitu; air yang suci lagi mensucikan, air yang suci tetapi makruh, air yang suci tetapi tidak mensucikan, air yang mengandung najis, dan air yang sedikit ukurannya. ${ }^{9} \quad$ Walaupun ada ulama yang membagi kepada empat kategori saja, ${ }^{10}$ selain yang kelima, tetapi dalam pembahasannya semuanya dijelaskan dengan baik. Untuk lebih jelasnya, penulis akan mengemukakan pembagian-pembagian itu satu persatu.

Air Yang Suci lagi mensucikan

Yaitu air yang suci lagi mensucikan biasa juga diistilahkan oleh ulama dengan air mutlak, yaitu air yang tidak berubah dari kondisi asalnya. Contoh air yang mutlak ini adalah air hujan, air sumur, air laut, air sungai, air embun, air salju, atau air suci yang bercampur dengan sesuatu yang suci tetapi tidak merubah warna, rasa, dan bau. Air inilah yang paling meyakinkan untuk dipakai dalam bersuci menurut kesepakatan ulama. ${ }^{11}$

Air yang mutlak bisa saja dimasuki oleh sesuatu yang suci, dan hal ini tidak merubah kesuciannya. Hal ini bisa terjadi karena beberapa hal:

Perubahan itu terjadi karena pengaruh tempatnya, misalnya air yang tergenang atau mengalir di batu belerang.

Perubahan terjadi karena lamanya air itu mengendap di suatu tempat, misalnya air

${ }_{9}$ Lihat Hasan ibn 'Amar ibn 'Ali al-Syarnabilali al-Mishri al-Hanafi, Nur al-Idhab wa Najab al-Arwab fi Fiqh al-Hanafi, (Ttp: al-Maktabah al-'Ashriyah, 2005), juz 1, 13-15; juga ibn Juzi al-Kalbi al-Farnathi, alQawanin al-Fiqbiyah, (Ttp: [tth]), juz 1, 25

10 Lihat antara lain al-Hajjah Kawkab 'Ubaid, Fiqh al-Tbadat 'Ala al-Madz̧ab al-Maliki, (Damaskus: Mathba'ah al-Insya , 1986), juz 1, 33-35

11 ibn Juzi al-Kalbi al-Farnathi, al-Qawanin..., 25 kolam yang tidak pernah dikuras.

Perubahan terjadi karena ada sesuatu yang hidup atau tumbuh di dalamnya, seperti adanya ikan dan tumbuhnya rumput di dalam air.

Perubahan terjadi karena masuknya tanah yang suci, atau dimasuki oleh daundaunan pohon yang tumbuh di sekitar kolam air itu.

\section{Air Yang Suci Tetapi Tidak Mensucikan}

Yaitu air yang menurut zatnya suci tetapi tidak sah dipakai untuk bersuci (wudhuk, mandi, menghilangkan najis). Air dalam kategori ini dapat dicontohkan sebagai berikut:

Air yang dimasuki oleh suatu benda yang suci dan benda tersebut merubah salah satu sifat air, yaitu warnanya, rasanya, dan baunya. Misalnya air yang dicampur dengan serbuk minuman, seperti air teh, kopi, coklat, dan jenis-jenis minuman lainnya. Air yang pada awalnya tidak punya nama (mutlak) akan berubah namanya sesuai dengan benda yang dimasukkan ke dalamnya.

Air yang tidak sampai dua qullah dan sudah terpakai sebelumnya untuk menghilangkan hadas atau najis, walaupun tidak terjadi perubahan pada sifat air setelah air itu dipakai. Dalam hadis-hadis Nabi SAW disebutkan bahwa air yang tidak sampai dua qullah rentan berubah menjadi air yang tidak dapat mensucikan. Salah satu bentuk air yang dibicarakan ulama dalam kategori ini adalah air musta'mal, yaitu air yang sisa yang jatuh dari anggota tubuh yang dibasuh. ${ }^{12}$ Menurut Mazhab Hanafi, Syafi'i, dan Hanbali, ${ }^{13}$ air ini

12 Hasan ibn 'Amar ibn 'Ali al-Syarnabilali alMishri al-Hanafi, Nur al-Idha.., 13

${ }^{13}$ Ibid. ; Abu al-Hasan Burhan al-Din, al-Hidayah fi Syarh Bidayah al-Mubtadi, (Beirut: Dar Ihya` al-Turats al-'Arabi, [tth]), juz 1, 22; Abû Bakar ibn Muhammad ibn 'Abd al-Mukmin ibn Hâriz ibn Ma'la al-Husainîy alHashanîy Taqiy al-Dîn al-Syâfi'î, (Kifâyah al-Akbyâr fi Hilli Ghâyah al-Ikhtishâr, (Damaskus: Dâr al-Khair, 1994), juz 1, 13-14; Musthafa ibn Sa'ad ibn 'Abdih alSuyuthi Syahrah al-Dimisyqi al-Hanbali, Mathalib Uli al- 
tidak boleh dipakai untuk bersuci, sedangkan dalam mazhab Maliki air musta'mal dalam pengertian di atas boleh dipakai untuk bersuci selama ia menganggap (berniat) bahwa anggota yang direndamkan itu adalah alat untuk mengambil air. ${ }^{14}$

Air yang keluar dari pohon atau buahbuahan, seperti air perasan tebu, air nira, air dalam bambu, air kelapa, dan sebagainya.

Air Yang Suci Tetapi Makruh Dipakai Untuk Bersuci

Contoh-contoh air dalam kategori ini dapat disebutkan sebagai berikut:

Air yang dipanaskan dengan sinar matahari atau disebut juga dengan air musyammas, walaupun air tersebut dalam jumlah yang cukup banyak. Hal ini berdasarkan hadis Nabi SAW kepada Aisyah ra, yang melarang Aisyah untuk memanaskan air dengan sinar matahari karena akan menimbulkan penyakit sopak. Walaupun makruh dipakai untuk mensucikan badan, tetapi boleh dipakai untuk mencuci pakaian dan membersihkan yang lainnya.

Memakai air yang sangat panas dan dan sangat dingin karena akan memberikan mudharat kepada anggota tubuh sehingga mengganggu kekhusyukan dalam menghadap Allah.

Air yang merupakan sisa minuman binatang peliharaan, seperti sisa kucing, sisa ayam, sapi, dan hewan ternak lainnya.

Air yang tergenang dalam jumlah yang sedikit yang telah dipakai untuk mandi berendam.

Air yang tergenang dan terdapat di dalamnya darah yang mengalir dari binatang yang mati di dalamnya, walaupun secara umum hal itu tidak merubah sifat air. Akan tetapi, jika terjadi perubahan sifat air, maka air itu menjadi

Nuba Fi Syarb Ghayah al-Muntaha, (Ttp: Maktabah alIslami, 1994), juz 1, 36-37

14 al-Hajjah Kawkab 'Ubaid, Fiqh al-Tbadat ..., 33 mutanajjis. ${ }^{15}$

\section{$\underline{\text { Air Mutanaijis }}$}

Sebagaimana diketahui bersama bahwa ulama sepakat tentang kedudukan air mutlak, air embun, air hujan, air sumur, dan air salju untuk dipakai dalam berwudhuk. Ulama juga sepakat bahwa air mutanajis tidak boleh dipakai untuk berwudhuk. Perbedaan yang terjadi terlihat dalam menilai air musta'mal, di mana sebagian ulama tidak membolehkannya sebagai air yang dipakai untuk berwudhuk, dan ini adalah pendapat ulama Syâfi'iyah dan Hanafiyah, sedangkan ulama Mâlikiyah membolehkannya.

Menurut Taqi al-Dîn al-Syâfi'î, pengarang kitab Kifâyah al-Akhyâr, pada dasarnya air dapat dikelompokkan kepada empat macam, yaitu;

1. Air yang suci lagi mensucikan dan tidak makruh, yaitu air mutlak.

2. Air yang suci lagi mensucikan tetapi makruh, yaitu air musyammas.

3. Air yang suci tetapi tidak mensucikan, di antaranya adalah air musta'mal.

4. Air yang terkena najis (mutanajjis). ${ }^{16}$

Dari keempat macam air ini, menurut Musthafâ al-Khîn dan Musthafâ al-Bughâ, hanya dua bentuk pertama yang dapat diyakini suci dan mensucikan, sedangkan macam ketiga dan apalagi yang keempat tidak layak untuk dijadikan sebagai alat untuk mensucikan. ${ }^{17}$ Persoalan yang mungkin terkait langsung dengan tema yang dibicarakan adalah tentang air mutanajjis, yaitu air yang sudah kena najis. Ada dua jenis air mutanajjis ini:

Pertama, air yang kadarnya banyak atau air yang kapasitasnya lebih dari dua qullah.

${ }^{15}$ Ibid., 33

16 Abû Bakar ibn Muhammad ibn 'Abd alMukmin ibn Hâriz ibn Ma'la al-Husainîy al-Hashanîy Taqiy al-Dîn al-Syâfi'î, (Kifâyah al-Akhyâr fi Hilli Ghâyah al-Ikhtishâr, (Damaskus: Dâr al-Khair, 1994),

17 Musthafâ al-Khîn dan Musthafâ al-Bughâ, alFiqh al-Manhâjîy 'Alâ Madžhab al-Imâm al-Syâfi'i, (Damaskus: Dâr al-Qalam, 1992), juz 1, 31 
Untuk kondisi air seperti ini diriwayatkan dari Abdullah ibn Umar Radhiyallahu 'anhuma, "Aku mendengar ketika Rasulullah SAW ditanya tentang hukum air yang terletak di tanah tak bertuan, air lain yang diminum oleh binatang buas dan melata, lalu Nabi SAW menjawab: ${ }^{18}$

عَنْ عَبْدِ اللَّهِ بْنِ عَبْدِ اللَّهِ بْنِ عُمَرَ، عَنْ أَبِيِهِ، قَالَ: سُئِلَ

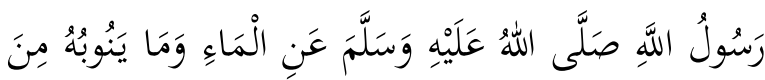

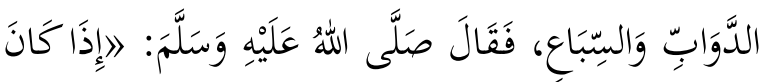

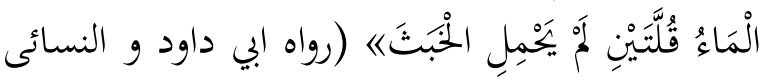<smiles>[13CH3]</smiles>

Dari 'Abdullâh ibn 'Abdullahb ibn Umar dari ayahnya (Umar) ra berkata, Rasulullah pernah ditanya tentang air yang terletak di tanah take bertuan, air lain yang diminum oleh binatang buas dan melata, lalu Nabi SAW menjawab: "Jika kadarnya dua qullah, tak mengandung najis." Dalam

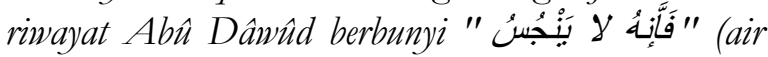

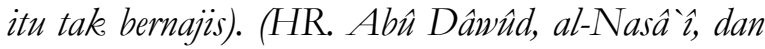
ibn Mâjab)

Air yang sampai dua qullah atau lebih tidak akan menjadi najis apabila ada najis yang masuk ke dalamnya kecuali mengubah sifat sifat air, yaitu berubah warnanya, rasanya, dan baunya.Walaupun demikian, perubahan ini menurut al-Khatîb al-Syurbainî tidak harus signifikan, karena sedikit saja berubah dari sifat awal air, maka ia akan menjadi air najis;

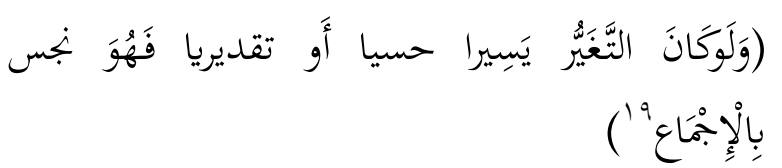

Menurut ibn Idrîs al-Bahûtîy alHanbalî, kedudukan air yang jatuh kepadanya najis walaupun sedikit, dan walaupun tidak nampak oleh mata tidak dapat dimaafkan (tidak boleh dipakai untuk bersuci) karena keumuman firman Allah SWT dalam surah al-

\footnotetext{
18 Abû Dâwûd Sulaimân, Sunan..., 17; al-Nasâ îy, al-Sunan..., 46; dan Ibn Mâjah Sunan..., 172

19 Syams al-Dîn Muhammad ibn Ahmad alKhatîb al-Syurbainîy al-Syâfî̀, al-Iqnâ' fi Hilli Alfẫ̧ $A b \hat{\imath}$ Sujâ', (Beirut: Dâr al-Fikr, [tth]), juz 1, 21
}

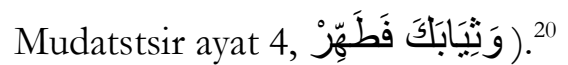

Kedua, Air yang kadarnya sedikit atau air yang kapasitasnya kurang dari dua qullah. Hadis di atas sekaligus juga menjadi dalil ketidaksucian air ini apabila dimasuki najis berdasarkan mafhum mukhalafah. Begitu najis masuk ke dalamnya, air ini langsung disebut air mutanajjis -sekalipun najisnya sedikit dan ciricirinya sebagai air tidak berubah, seperti warna, aroma, dan rasa. Ukuran dua qullah adalah 500 liter Baghdad, yang setara dengan 192, $857 \mathrm{~kg}$. Ukuran kubiknya, 1,25 hasta (panjang, lebar dan tinggi). Satu hasta yakni sepanjang dari ujung ke siku (orang dewasa).

Dari hadis di atas dapat dipahami bahwa apabila air kurang dari dua qullah, dan dimasuki oleh benda najis, dihukum sebagai air najis sekalipun tidak berubah rasa, warna, dan aromanya. Pengertian di atas didukung oleh hadits riwayat Muslim dari Abû Hurairah bahwa Nabi SAW bersabda: ${ }^{21}$

$$
\begin{aligned}
& \text { "إِذَا اسْتَيْقَظَ أَحَدُكُّمْ مِنْ نَوْمِهِ فَلاَ يَغْمِسنْ يَدَهُ في الإنَاءٍ }
\end{aligned}
$$

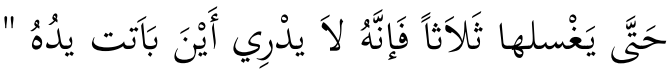

"Iika salah satu dari kalian bangun tidur, janganlah langsung mencemplungkan tangannya ke dalam wadah air sebelum membasubnya 3 kali karena ia tidak tabu tempat tangannya tadi malam." (H.R. Mus(im).

Di dalam hadits ini, Nabi SAW melarang seseorang yang baru bangun tidur untuk langsung mencemplungkan tangannya ke air, khawatir tercampur dengan najis yang tak terlihat. Maklum, najis yang tak terlihat bisa membuat air berubah. Nabi SAW tentu tidak melarang hal tersebut apabila dimasukkannya tangan ke dalam air tidak menyebabkannya terkena najis.

Dengan demikian, air yang kadarnya

20 Manshûr ibn Yûnus ibn Shalâh al-Dîn in Hasan ibn Idrîs al-Bahûtîy al-Hanbalîy, Kasyf al-Iqnâ' 'An Matan al-Iqnâ', (Beirut: Dâr al-Kutub al-ilmiyah, [tth], juz 1, 189

${ }^{21}$ Muslim ibn Hajjâj Abû al-Hasan al-Qusyairî al-Naisabûrî, al-Musnad al-Shabî.., 233 
banyak, yakni berkapasitas dua qullah atau lebih tidak serta merta menjadi mutanajjis hanya dengan jatuhnya suatu najis ke dalamnya. Tetapi ia akan menjadi air mutanajjis, jika salah satu dari ketiga cirinya, yakni warna, rasa atau bau, mengalami perubahan terlebih dahulu. Dasarnya adalah ijma' para ulama. Imam al-Nawawiy mengungkapkan:

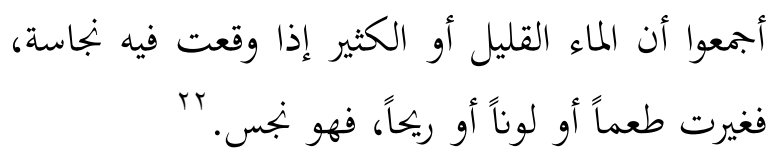

"Menurut kesepakatan ulama, air dengan kadar yang sedikit ataupun banyak dan berubah rasa, warna, atau baunya karena tercampur najis, maka air tersebut menjadi air bernajis."

Dengan demikian tidak hanya air yang sedikit yang dimungkinkan menjadi air mutanajjis, bahkan air yang kadarnya banyak juga dimungkinkan menjadi air yang bernajis.

\section{Air Yang Berada Pada Bak Pembasuh Kaki di Tempat Berwudhuk}

Sebagaimana dikemukakan sebelumnya bahwa yang menjadi fokus pembicaraan dalam tulisan ini adalah tentang kolam air kecil atau bak yang digunakan untuk membasuh kaki sebelum dan sesudah berwudhuk. Hal ini sebenarnya tidak terkait dengan kebasahan wudhuk seseorang ketika ia sudah melaksanakan rukun dan syarat yang ditentukan. Tetapi yang mengusik dan menimbulkan pertanyaan adalah berkenaan dengan kesucian air yang diinjak setelah selesai berwudhuk yang terdapat pada sebagian masjid.

Sebagai ilustrasi, pada saat seseorang masuk ke tempat berwudhuk, maka maka ia akan memasukkan kakinya ke dalam bak kecil di depan pintu tempat wudhuk. Kita tidak pernah tahu apa yang terdapat pada kaki

22 Abû Zakariyâ Muhyi al-Dîn Yahyâ ibn Syarf al-Nawawiy, al-Majmû' Syarh al-Mubadzdzab, (Beirut: Dâr al-Fikr, [tth]), juz 1, 110 dan 350 seseorang ketika itu. Banyak kemungkinan kondisi kaki yang masuk ke dalam bak tersebut, misalnya kaki yang berbau, kaki yang menginjak benda najis, kaki yang kotor karena selesai berjalan di pasar, kaki yang sakit gatalgatal, dan sebagainya. Kotoran-kotoran yang ditinggalkan oleh kaki-kaki yang banyak itu salah satunya dimungkinkan meninggalkan najis.

Walaupun apa yang dibicarakan ini secara langsung tidak mengganggu terhadap rukun wudhuk yang dilakukan, tetapi setidaknya menimbulkan persangkaan bahwa salah satu anggota wudhuk, dalam hal ini kaki, sudah terkontaminasi oleh air yang seharusnya tidak boleh dipakai untuk bersuci. Mungkin seseorang akan enggan apabila di air kolam itu ia disuruh kembali untuk membasuh mukanya dan anggota wudhuk yang lainnya. Ini menunjukkan bahwa air tersebut memang tidak layak dan pantas dipertanyakan untuk merendamkan kaki setelah berwudhuk.

Hal ini sejalan dengan firman Allah SWT dalam surah al-Mudatstsir ayat 4, bahwa salah satu syarat untuk menghadap kepada Allah (dalam hal ini shalat) harus suci pakaian, termasuk dalam hal ini anggota tubuh yang akan dibawa menghadap Allah SWT. Mestinya setelah berwudhuk seseorang sudah mendapatkan kesucian yang sempurna, namun dengan memasuki kolam air kecil itu kesuciannya menjadi terganggu. Hal ini tentunya berhubungan dengan kolam air yang kadar airnya sedikit dan tidak mengalir. Namun apabila airnya mengalir, atau berbedanya kolam air tempat masuk dan keluar dari tempat berwudhuk, dimungkinkan tidak ada masalah di dalamnya.

Berkenaan dengan kondisi air di atas, di mana kadar airnya sedikit tidak sampai dua qullah dan juga tidak mengalir, maka terdapat hal-hal yang negatif di sana. Di samping ada unsur menjiiikkan, juga dimungkinkan ada kuman-kuman penyakit-penyakit yang bertebaran di sana, di samping alasan-alasan 
lainnya. Oleh karena itu tanpa mengecilkan arti dari kreasi dan inovasi dan yang dibuat oleh sebagian masjid, maka kesimpulan dari persoalan ini bahwa kolam kecil tempat tempat mencuci kaki sebelum masuk tempat berwudhuk itu kurang sesuai dengan kesucian yang diinginkan dalam rangka menghadap Allah SWT. Apabila dilihat dari tinjauan hukum Islam, maka keberadaan bak air tersebut hukumnya makruh. Hal ini karena tidak dapat dipastikan adanya najis yang masuk ke dalam air tersebut. Namun dapat diduga secara kuat (mazhinnah li al-hukm) bahwa air tersebut sudah terkontaminasi oleh najis ataupun kuman-kuman penyakit yang akan berpindah kepada orang lain yang juga merendamkan kakinya ke dalam air itu. Akan tetapi apabila terdapat keyakinan dan dapat dibuktikan secara lahiriyah dan ilmiah bahwa air itu ternajisi dan mengandung kumankuman penyakit dengan beragamnya kaki yang masuk ke dalamnya, maka tentunya hukum membuat bak air itu menjadi haram. Hal ini sesuai dengan kaidah fiqh yang menyatakan "tidak boleh memudharatkan orang lain dan tidak boleh pula dimudharatkan" dan "kemudharatan itu harus dhilangkan". ${ }^{23}$ Berdasarkan kaidah fiqh di atas, maka kehatihatian (ibtiyâth) dalam melakukan sesuatu mutlak harus diperhatikan termasuk dalam melakukan kreatifitas dalam melaksanakan ibadah, khususnya ibadah wudhuk.

\section{KESIMPULAN}

Dari pembahasan sebelumnya dapat disimpulkan hal-hal sebagai berikut:

Pada dasarnya ketika seseorang melakukan wudhuk sesuai dengan syarat dan rukun wudhuk, maka wudhuknya sudah sah. Apabila tempat masuk dan keluar tempat berwudhuk sama, dan air pada bak pembasuh kaki itu kurang dari dua qullah dan tidak mengalir,

23 Gharrat Ubaid al-Da'âs, al-Qawâ'id al-Fiqhiyah Ma'a al-Syarh al-Mujâz, (Beirut: Dâr al-Tirmidzi, 1989), cet.ke-3, 28 dan 31 maka diduga secara kuat (mazhinnah) bahwa air itu dimasuki oleh najis dan kotoran-kotoran dari banyaknya kaki yang masuk ke dalamnya. Kesucian sempurna yang diinginkan ketika menghadap Allah SWT (shalat) tidak akan tercapai, dan diduga juga secara kuat akan menyebarkan berbagai penyakit dan kuman kepada orang lain. Oleh karena itu makruh hukumnya menyiapkan bak pembasuh kaki seperti itu. Akan tetapi apabila ditemukan kepastian, baik secara lahiriyah maupun ilmiah bahwa air itu betul-betul menjadi ternajisi oleh kaki-kaki-kaki yang masuk ke dalamnya dan dapat pula dipastikan terkontaminasi oleh berbagai kuman penyakit, maka hukum membuat bak semacam itu makruh.

Apabila bak pembasuh kaki itu berbeda antara tempat masuk dan keluar dari tempat berwudhuk, maka hal ini dapat dibenarkan (mubah) walaupun airnya tidak sampai dua qullah, karena pada saat keluar dari tempat berwudhuk kaki yang masuk ke dalam bak pembasuh kaki itu sudah suci. 


\section{DAFTAR KEPUSTAKAAN}

al-Azadi, Abû Dâwûd Sulaimân ibn al-Asy'ab ibn Ishâq ibn Basyîr ibn Syidâd ibn Umar, Sunan Abî Dâwûd. Juz 1. Beirut: al-Maktabah al-'Ishriyah, [tth]

al-Bahûtîy al-Hanbalîy, Manshûr ibn Yûnus ibn Shalâh al-Dîn in Hasan ibn Idrîs, Kasyf al-Iqnâ' 'An Matan al-Iqnâ'. Juz 1. Beirut: Dâr al-Kutub al-ilmiyah, [tth]

al-Bâqi, Muhammad Fu'âd 'Abd, al-Lu'lu' wa al-Marjân fî̀ Mâ Ittifâq al-Syaikhân. Juz 1. Beirut Libanon: Dâr al-Fikr, [tth]

Burhan al-Din Abu al-Hasan, al-Hidayah fi Syarb Bidayah al-Mubtadi. Juz 1. Beirut: Dar Ihya`alTurats al-'Arabi, [tth]

al-Bukhârî al-Ja'fîy, Muhammad ibn Ismâ'îl Abu Abdillâh, al-Jâmi' al-Musnad al-Shabîh alMukhtashar min Umûr Rasûlillâh $S A W$ wa Sunanuh wa Ayyâmub. Juz 1. Dâr al-Thawwâf alNajâh, [tth]

al-Da'âs, Gharrat Ubaid, al-Qawâ'id al-Fiqhiyah $M a^{\prime} a$ al-Syarh al-Mujầ. Cet.3. Beirut: Dâr alTirmidzi, 1989

al-Dimisyqi al-Hanbali, Musthafa ibn Sa'ad ibn 'Abdih al-Suyuthi Syahrah, Mathalib Uli al-Nuba Fi Syarh Ghayah al-Muntaha. Juz 1. Ttp: Maktabah al-Islami, 1994

al-Farnathi, ibn Juzi al-Kalbi, al-Qawanin al-Fiqhiyah. Juz 1. Ttp: [tth]

al-Ghâzî, Muhammad ibn al-Qâsim, Fath al-Qarîb al-Mujîb. Indonesia: Dâr al-Ihyâ` al-Kitâb al'Arabiyah, [tth]

al-Jazînî, 'Abd al-Rahmân, al-Fiqh 'Alâ Madzâhhib al-Arba'ah. Juz 1. Kairo: Mathba'ah Istiqâmah, [tth]

al-Khîn, Musthafâ dan Musthafâ al-Bughâ, al-Fiqh al-Manhâjîy 'Alâ Madžbab al-Imâm al-Syâfíi. Juz 1. Damaskus: Dâr al-Qalam, 1992

al-Malibârî, Zain al-Dîn ibn 'Abd al-Azîz, Fath al-Mu'în bi Syarh al-Qurrata al-Uyûn. Semarang: Karya Toha Putra, [tth]

Munawwir, Ahmad Warson, Kamus Al-Munawwir. Yogyakarta: Pustaka Progresif, 1997

al-Naisabûrî , Muslim ibn Hajjâj Abû al-Hasan al-Qusyairî, al-Musnad al-Shabîh al-Mukhtashar Bi Naql al'-Adl Ilâ Rasûlillâh SAW. Juz 1. Beirut: Dâr Ihyâ` al-Turâts al-'Arabiy, [tth]

al-Nasâ'îy, Abû Abdirrahmân Ahmad ibn Syu'aib ibn Ali al-Kharasânîy, al-Sunan al-Shughrâ li alNasâ'îy. Juz 1. Halab: Maktab al-Mathbu'ât al-Islâmiyah, 1987

al-Nawawîy, Abû Zakariyâa Muhyi al-Dîn Yahyâ ibn Syarf, al-Majmû̉' Syarh al-Muhadżdżab. Juz 1. Beirut: Dâr al-Fikr, [tth]

al-Quzwainîy, Ibn Mâjah Abû Abdillâh Muhammad ibn Yazîd, Sunan Ibn Mâjah. Juz 1. Dâr alIhyâ` al-Kutub al-'Arabiyah, [tth] 
Sâbiq, Sayyid, Fiqh al-Sunnah. Juz 1. Kairo: Thabâ'ah Khassah al-Fathu Li al-I’lâm al-‘Arabi, 1365 $\mathrm{H}$

al-Syarnabilali al-Mishri al-Hanafi, Hasan ibn 'Amar ibn 'Ali, Nur al-Idhah wa Najah al-Arwah fi Fiqh al-Hanafi. Juz 1. Ttp: al-Maktabah al-'Ashriyah, 2005

al-Syurbainîy al-Syâfi'î, Syams al-Dîn Muhammad ibn Ahmad al-Khatîb, al-Iqnâ' fi Hilli Alfâz̆ Abî Sujâ'. Juz 1. Beirut: Dâr al-Fikr, [tth]

'Ubaid, al-Hajjah Kawkab, Fiqh al-Tbadat 'Ala al-Madz̧bab al-Maliki. Juz 1. Damaskus: Mathba'ah al-Insya`, 1986

Taqiy al-Dîn al-Syâfi'̂̂, Abû Bakar ibn Muhammad ibn 'Abd al-Mukmin ibn Hâriz ibn Ma'la alHusainîy al-Hashanîy, Kifâyah al-Akhyâr fi Hilli Ghâyah al-Ikhtishâr. Damaskus: Dâr al-Khair, 1994 
